\title{
Spore morphology of Parahemionitis arifolia (Cheilanthoideae, Pteridaceae)
}

\author{
A. V. Vaganov ${ }^{1}$, I. I. Gureyeva ${ }^{2}$, A. I. Shmakov ${ }^{1}$, A. A. Kuznetsov², R. S. Romanets ${ }^{2}$ \\ ${ }^{1}$ South-Siberian Botanical Garden, Altai State University, pr. Lenina, 61, Barnaul, 656049, Russia. \\ E-mail:vaganov_vav@mail.ru \\ ${ }^{2}$ Tomsk State University, pr. Lenina, 36, Tomsk, 634050, Russia.E-mail: gureyeva@yandex.ru
}

Keywords: Cheilanthoideae, China, Parahemionitis, Pteridaceae, spore, sculpture of perispore, scanning electronic microscopy (SEM).

Summary. A study of spores of the single species of the genus Parahemionitis Panigrahi was performed using the method of scanning electronic microscopy (SEM). Spores of Parahemionitis arifolia (Burm. f.) Panigrahi are tetrahedral trilete, roundish-triangular in polar position, with micro-wrinkled exospore and sculptured perispore. Sculpture of perispore is cristate-reticulate, cristae are quite regularly distributed and form reticulum with small mostly closed polygonal luminae of different shape. Laesura arms are often obscured by numerous cristae. Size of spores is 53-63 $\times$ $40-42 \mu \mathrm{m}$. Spores of $P$. arifolia are similar in perispore sculpture with those of species of some cheilanthoid ferns.

\section{Морфология спор Parahemionitis arifolia (Cheilanthoideae, Pteridaceae)}

\author{
А. В. Ваганов ${ }^{1}$, И. И. Гуреева ${ }^{2}$, А. И. Шмаков ${ }^{1}$, А. А. Кузнецов ${ }^{2}$, Р. С. Романец ${ }^{2}$ \\ ${ }^{1}$ Южно-Сибирский ботанический сад, Алтайский государственный университет, \\ пр. Ленина, 61, г. Барнаул, 656049, Россия \\ ${ }^{2}$ Томский государственный университет, пр. Ленина, 36, г. Томск, 634050, Россия
}

Ключевые слова: Китай, сканирующая электронная микроскопия (СЭМ), скульптура периспория, споры, Cheilanthoideae, Parahemionitis, Pteridaceae.

Аннотация. Методом сканирующей электронной микроскопии (СЭМ) проведено исследование спор единственного вида рода Parahemionitis Panigrahi. Споры Parahemionitis arifolia (Burm. f.) Panigrahi тетраэдрические, трехлучевые, округло-треугольные в полярном положении, с мелкоморщинистым экзоспорием и скульптурным периспорием. Скульптура периспория гребенчато-сетчатая. Гребни (кристы) расположены упорядоченно и образуют густую сеть из ячеек небольшого размера различной формы. Лезура большей частью скрыта многочисленными кристами. Размер спор 53-63 × 40-42 мкм. Споры P. arifolia сходны по скульптуре периспория со спорами некоторых видов хейлантоидных папоротников.

The genus Parahemionitis Panigr. was described by G. Panigrahi in 1993 on the base of single species Asplenium arifolium Burm. f. selected as the type of this new genus. In turn, Asplenium arifolium was first proposed by N. L. Burmann in "Flora Indica" (Burmann, 1768). Later, it was transferred to Hemionitis L. by T. Moore (1859), who suggested a new combination Hemionitis arifolia (Burm. f.) T. Moore. In 1974 C. V. Morton and then in 1997 C. R. Fraser-Jenkins rejected the name Asplenium arifolium as based on the type specimen determined by A. Alston (Aug. 1952, in scheda) as belonging to another species - Acrostichum aureum L. If so, C. V. Morton (1974) suggested Hemionitis cordata Roxb. 
ex Hook. et Grev. as a correct name for this taxon. C. R. Fraser-Jenkins (1997) used this name as basionim for new suggested combination Parahemionitis cordata (Roxb. ex Hook. et Grev.) Fras.-Jenk.

The problem with correct name for discussed species was resolved by J. Mazumdar (2015). He found out, that figures by Petiver's $(1702$, t. 50 , f. 12) and van Rhede tot Drakestein's (1692-1703, Tabula 10, Fig.) showing auriculate sinuous fronds were mentioned in the N. L. Burmann's protologue and his diagnosis was based on these figures. Therefore J. Mazumdar (2015) selected figure by van Rhede tot Drakestein's from "Hortus Indicus Malabaricus" (1703) as lectotype. On the cause of no collection data is available for the specimen on which this drawing was based, J. Mazumdar (2015) selected epitype; it is the herbarium specimen collected by him: "India. West Bengal: Burdwan, Kanchannagar, near bridge above canal, 30 m, 21 Nov 2007, J. Mazumdar 59" (CAL). In this case, the name Asplenium arifolium Burm. f. is correct basionym for considered taxon, and the genus Parahemionitis based on this species is valid.

C. R. Fraser-Jenkins (1997) in his large publication "New species syndrome in Indian pteridology and the ferns of Nepal" wrote that J. T. Mikel (1974) had suggested the possibility of description of a new genus for this species, but considered this inappropriate and related it to the genus Hemionitis. But T. Ranker (1989) has shown the Indian fern definitely does not belong to true Hemionitis. J. T. Mikel and T. Ranker had not formalized their idea about separate genus by publishing a new genus. More reasons for description of a new genus on the base of "Hemionitis" arifolia gave R. Tryon. He has written that it is "a morphologically isolated species of uncertain affinity" (Tryon, 1986, p. 186) and "not readily included in any recognized genus" (Tryon et al., 1990, p. 245). Later A. Tryon and B. Lugardon (1991, p. 173) mentioned that "the widely distributed Asiatic Hemionitis arifolia (Burm.) Moore is an apogamous tetraploid that is excluded [from Hemionitis] on the basis of its distinctive morphology". They considered also that specific of flavonoid composition of this species, found out by D.E. Giannasi and J.T. Mikel (1979), was the important reason for its excluding from Hemionitis (Tryon and Lugardon, 1991). 'Hemionitis' arifolia contains only three of the 16 flavonoid compounds recognized in other species of Hemionitis and only four flavonoids that occur in "Hemionitis" arifolia are absent in others (Giannasi, 1974; Giannasi, Mikel, 1979; Tryon, Lugardon, 1991).
All of suggestions were realized by G. Panigrahi, who undertook three attempts of description of new genus on the base of Asplenium arifolia (Panigrahi, 1991, 1992, 1993). In the first two descriptions (Panigrahi, 1991, 1992) he did not follow "The International code of botanical nomenclature", publication of the description of the genus Parahemionitis in 1993 (Panigrahi, 1993) was valid.

In the last Pteridophyta systems Parahemionitis is considered as a member of the Pteridaceae (Smith et al., 2006). M. J. M. Christenhusz et al. (2011) consider Parahemionitis as synonym of the large genus Hemionitis, which is attributed to the subfamily Cheilanthoideae of the large family Pteridaceae. "A community-derived classification for extant lycophytes and ferns" (Pteridophyte Phylogeny Group, 2016) includes Parahemionitis as the separate genus belonging to subfamily Cheilanthoideae of Pteridaceae family.

E. Schuetpelz et al. (2007) determined phylogenetic relationships within the Pteridaceae using three plastid genes (rbcL, atpB, and atpA). Parahemionitis arifolia is nested in the large cheilanthoid clade, which corresponds to subfamily Cheilanthoideae, and is sister to the clade formed by Hemionitis species. Similar results were obtained by G.-M. Zhang et al. (2009). They conducted special study of the systematic position of Parahemionitis arifolia (under the name Parahemionitys cordata) based on the analysis of rbcL-gene sequence. Their study confirmed removing discussed species from Hemionitis to the separate genus Parahemionitis.

Thus, the nomenclatural citation for this genus is: Parahemionitis Panigrahi, 1993, Amer. Fern J. 83(3): 90. Type: Parahemionitis arifolia (Burm. f.) Panigrahi (Asplenium arifolium Burm. f.). The genus Parahemionitis is monotypic, represented by the single species $-P$. arifolia, growing in India and Sri Lanka throughout continental South-East Asia to southern China, Taiwan and the Philippines (Winter, Amoroso, 2003). The nomenclatural citation for the species is the following: Parahemionitis arifolia (Burm. f.) Panigrahi, 1993, Amer. Fern J. 83(3): 90. - Asplenium arifolium Burm. f., 1768, Fl. Ind.: 231. - Hemionitis arifolia (Burm. f.) T. Moore, 1859, Index Fil.: 114. - Hemionitis cordata Roxb. ex Hook et Grev., 1828, Icon. Fil. 1: 64. Parahemionitis cordata (Roxb. ex Hook. et Grev.) Fras.-Jenk., 1997, New species syndrome in Indian pteridology and the ferns of Nepal: 187. Lectotype (Mazumdar, 2015: 91): "van Rhede tot Drakestein, Hortus Indicus Malabaricus 12: 21, tabula 10, 1703 (Fig. 2)"; Epitype (Mazumdar, 2015: 91): "India. 
West Bengal: Burdwan, Kanchannagar, near bridge above canal, 30 m. 21 XI 2007. J. Mazumdar 59".

The aim of this study is to provide details of morphology and ornamentation of spores of Parahemionitis arifolia using scanning electronic microscopy (SEM) to reveal features useful for systematics and phylogenetics.

\section{Materials and methods}

Spores were obtained from herbarium specimen of Parahemionitis arifolia, stored in PE (Chinese National Herbarium, Chinese Academy of Sciences, Beijing). Mature spores were used for SEM observations. Spores were mounted on SEM stubs using double-sided carbon adhesive tape and coated with gold in a "Quorum Q150R S" sputtercoater. Stubs were viewed and photographed with the scanning electron microscope "Mini-SEM SNE-4500M" in the Laboratory of Structural and Molecular Analysis of Plants (Tomsk State University, Tomsk, Russia). Spore surface was scanned in a high vacuum at voltage of $20 \mathrm{kV}$, through 2000-2500× magnification. Equatorial diameter (distal or proximal position of spore), polar axis (equatorial position of spore), length and width of laesura arms (proximal position of spore) were measured. All measurements were made on SEMmicrographs of spores using the computer program "Image J". For terminology of sculpture elements, we primarily followed A. Tryon and B. Lugardon (1991), shape of the distal and proximal sides was described using terms by B. K. Nayar and S. Devi (1966). Spelling of the names of taxa and authors is given according to "The International Plant Name Index" (http://www.ipni.org).

\section{Results and discussion}

Parahemionitis arifolia forms typical for Pteridaceae tetrahedral trilete spores (Fig. 1). Spores are roundish-triangular in polar position, with convex sides and wide-rounded corners. In equatorial position, the distal side is hemispherical, proximal side is broadly conical. Spores have plain exospore and sculptured perispore. Exospore is micro-wrinkled, visible in case of destruction of fragile perispore. Perispore on the proximal and distal sides is cristate-reticulate, the cristae are more or less long and thin $(1.5 \mu \mathrm{m}$ in mean), with uneven upper margin, quite regularly distributed and form reticulum with small mostly closed polygonal luminae of different shape. Equatorial diameter ranges from 53.2 to $63.5 \mu \mathrm{m}$ (mean $56.9 \mu \mathrm{m}$ ), polar axis is $40.3-41.5 \mu \mathrm{m}$ (mean $41.4 \mu \mathrm{m}$ ), inner size of luminae is $3.4-8.1 \mu \mathrm{m}$ (mean $4.6 \mu \mathrm{m}$ ). Laesura arms are straight, $20.0-23.5 \mu \mathrm{m}$ (mean $21.3 \mu \mathrm{m}$ ) in length and 0.9-2.2 $\mu \mathrm{m}$ (mean $1.5 \mu \mathrm{m}$ ) in width, often obscured by numerous cristae.

Investigated specimen: China, Hainan. Coll. Mr. W. Hancock. 1898. № 117B. № 01644177 (PE).

Spore having cristate perispore are characteristic for cheilanthoid ferns, in particular for some species of Bommeria E. Fourn., Cheilanthes Sw., Doryopteris J. Sm., Hemionitis L., Notholaena R. Br., Paraceterach Copel., Pellaea Link, Trachypteris André ex Christ (Tryon, Lugardon, 1991). Judging by the given photos by Tryon and Lugardon (1991), cristae are different in dimensions and distribution on the surface of spore. Spores of Parahemionitis arifolia despite of mentioning of this species were not used in Tryon-Lugardon's publication, but they supposed in this species "cristate spores similar to those of several genera in the subfamily Cheilanthoideae" (Tryon, Lugardon, 1991, p. 173). B. K. Nayar and S. Devi (1967), who studied spores of this species collected in India under the light microscope, described them as having "perine closely adherent to the exine and skin-like, smooth and wrinkled into thin, apparently solid folds 4-6 mm tall, $1.5 \mathrm{~mm}$ thick with irregular crest and coalesced to form a reticulate pattern" (p. 583). They indicated the dimensions of spores as $36 \times 48 \mu \mathrm{m}$, length of laesura as $14 \mu \mathrm{m}$. Spores of Parahemionitis arifolia are most similar in dimensions and sculpture of perispore to spores of Bommeria ehrenbergiana (K1.) Underw. and $B$. hispida Underw. judging by the photos given by A. Tryon and B. Lugardon (1991) for these species in their monograph. In contrast with it, Parahemionitis arifolia and species of Bommeria belongs to different clades in the molecular study (Schuettpelz et al., 2007; Zhang et al., 2009).

Thus, spores of Parahemionitis arifolia differs from the spores of other cheilanthoid ferns having cristate-reticulate perispore by more densely arranged cristae, forming reticulum with small closed polygonal luminae.

\section{Acknowledgements}

We are grateful to curators of the Herbarium of Institute of Botany, Chinese Academy of Sciences (PE, Beijing) for the possibility of obtaining of spores from the herbarium material. The study was supported by RFBR (project No. 16-04-00513) and by the Tomsk State University competitiveness improvement program. 

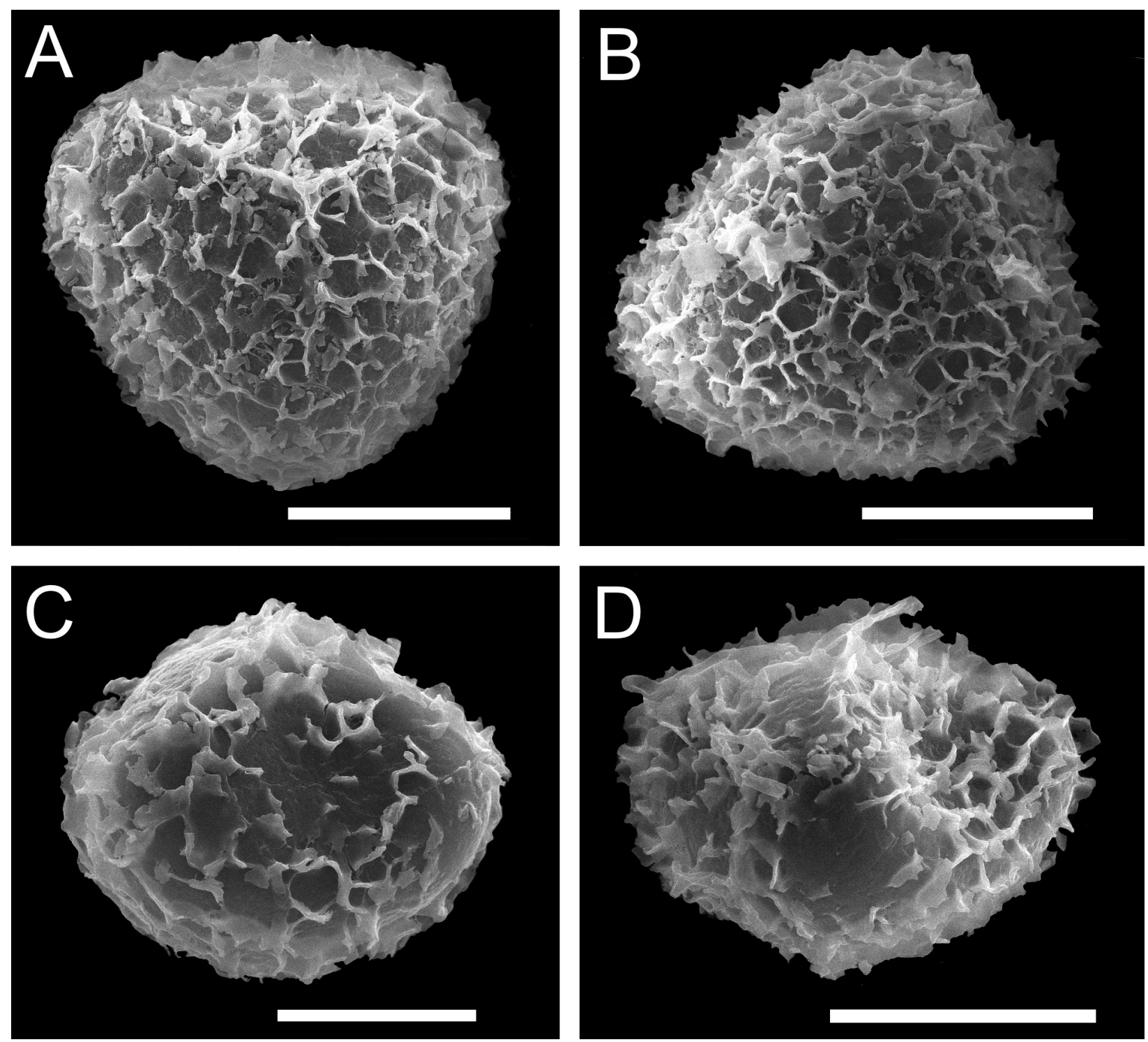

Fig. 1. SEM-micrographs of spores of Parahemionitis arifolia (Burm.) Panigrahi: A - proximal side of spore, laesura arms are obscured by numerous cristae; B - distal side of spore; C, D - spore in equatorial position, laesura above. Spores on $\mathrm{C}$ and $\mathrm{D}$ have fragment of destroyed perispore, where wrinkled exospore is visible. Scale bars: A, B, D $30 \mu \mathrm{m}, \mathrm{C}-20 \mu \mathrm{m}$.

\section{REFERENCES}

Burmanni N. L. 1768. Flora Indica: cui accedit series zoophytorum Indicorum, nec non prodromus florae Capensis. Apud Cornelium Haek, Amsterdam, 32 pp. DOI: https://doi.org/10.5962/bhl.title.60581

Christenhusz M. J. M., Zhang X.-Ch., Schneider H. 2011. A linear sequence of extant families and genera of lycophytes and ferns. Phytotaxa 19: 7-54. DOI: doi.org/10.11646/phytotaxa.19.1.2.

Fraser-Jenkins C. R. 1997. New species syndrome in Indian pteridology and the ferns of Nepal. International Book Distributors, Dehra Dun, India, 404 pp.

Giannasi D. E. 1974. Phytochemical aspects of fern systematics. Ann. Mo. Bot. Gard. 61: 368-378.

Giannasi D. E., Mickel J. T. 1979. Systematic implications of the flavonoid pigments in the fern genus Hemionitis (Adiantaceae). Brittonia 31: 405-412.

Mazumdar J. 2015. Nomenclatural note on Hemionitis arifolia (Pteridaceae). Fern. Gaz. 20, 2: 91-94.

Mickel J. T. 1974. A redefinition of the genus Hemionitis. Amer. Fern. J. 64, 1: 3-12.

Moore T. 1859. Index Filicum. W. Pamplin, London, 109-156 pp. DOI: doi.org/10.5962/bhl.title.55301

Morton C. V. 1974. William Roxburgh's fern types. Contributions U. S. Nat. Herb. 38(7): 283-396. URL: http:// www.biodiversitylibrary.org/item/13798 (Accessed 15.07.2018). 
Nayar B. K., Devi S. 1966. Spore morphology of the Pteridaceae. I. The Pteridoid ferns. Grana Palinologica, 6: 476-479. DOI: 10.1080/00173136609430036.

Nayar B. K., Devi S. 1967. Spore morphology of the Pteridaceae II. The Gymnogrammoid ferns. Grana Palynologica, 7(2-3): 568-600. DOI: 10.1080/00173136709430049.

Panigrahi G. 1991. Pteridophytes flora of Orissa. Abstracts and Souvenir Booklet, National Symposium on Current Trends in Pteridology, 4-6 October 1991, Palayamkottai, Tamilnadu, India: 12-13.

Panigrahi G. 1992. Nomenclatural notes on "Hemionitis" arifolia (N. Burm.) Moore (Pteriaceae [sic]). Proc. 79th Ind. Sci. Congr., Part 3 (Abstracts): 49.

Panigrahi G. 1993. Parahemionitis, a new genus of Pteridaceae. Amer. Fern J. 83(3): 90-92.

Pteridophyte Phylogeny Group. 2016. A community-derived classification for extant lycophytes and ferns. J. Syst. Evol. 54, 6: 563-603. DOI: doi.org/10/1111/jsp12229

Ranker T. 1989. Spore morphology and generic delimitation of New World Hemionitis, Gymnopteris and Bommeria (Adiantaceae). Amer. J. Bot. 76(2): 297-306.

Schuettpelz E., Schneider H., Huiet L., Windham M. D., Pryer K. M. 2007. A molecular phylogeny of the fern family Pteridaceae: assessing overall relationships and the affinities of previously unsampled genera. Mol. Phylogenet. Evol. 44(3): 1172-1185. DOI: doi.org/10.1016/j.ympev.2007.04.011

Smith A. R., Kathleen M. P., Schuettpelz E., Korall P., Schneider H., Wolf P. G. 2006. A classification for extant ferns. Taxon 3, 55: 705-731. DOI: doi.org/10.2307/25065646

Tryon A. F., Lugardon B. 1991. The spores of pteridophytes: surface, wall structure, and diversity based on electron microscopy studies. Springer-Verlag, Berlin, $648 \mathrm{pp}$.

Tryon R. M. 1986. Some new names and combinations in Pteridaceae. Amer. Fern J. 76, 4: 184-186.

Tryon R. M., Tryon A. F., Kramer K. U. 1990. Pteridaceae. In: The families and genera of vascular plants. Vol. 1. Pteridophytes and Gymnosperms. Volume Editors: K. U. Kramer, P. S. Green. Springer-Verlag, Berlin, Heidelberg GmbH, 230-256 pp.

Zhang G.-M., Liu H.-M., Yang W.-L., Zhang X.-Ch. 2009. Systematic position of Hemionitis arifolia based on the analysis of rbcL sequences. Journal of Beijing Forestry University 31(6): 15-18.

Winter W. P., Amoroso V. B. (eds). 2003. Plant resources of South-East Asia. № 15(2). Cryptogams: Ferns and fern allies. Backhuys Publishers, Leiden, The Netherlands, 268 pp. 